\title{
Caring of the Fringe? Mediterranean Desertification between Peri-Urban Ecology and Socioeconomics
}

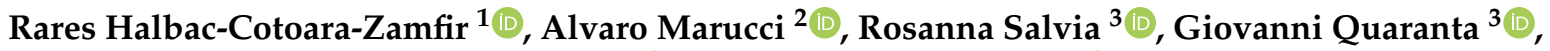 \\ Adele Sateriano ${ }^{4, *}$, Massimo Cecchini ${ }^{2}$ (1) and Leonardo Bianchini ${ }^{2}$ (i) \\ 1 Department of Overland Communication Ways, Foundation and Cadastral Survey, \\ Politehnica University of Timisoara, 300224 Timisoara, Romania; rares.halbac-cotoara-zamfir@upt.ro \\ 2 Department of Agricultural and Forestry Sciences (DAFNE), University of Tuscia, I-01100 Viterbo, Italy; \\ marucci@unitus.it (A.M.); cecchini@unitus.it (M.C.); 1.bianchini@unitus.it (L.B.) \\ 3 Department of Mathematics, Computer Science and Economics, University of Basilicata, \\ I-85100 Potenza, Italy; rosanna.salvia@unibas.it (R.S.); giovanni.quaranta@unibas.it (G.Q.) \\ 4 Independent Researcher, I-00185 Rome, Italy \\ * Correspondence: adele.sateriano.pul@gmail.com
}

Citation: Halbac-Cotoara-Zamfir, R.; Marucci, A.; Salvia, R.; Quaranta, G.; Sateriano, A.; Cecchini, M.; Bianchini, L. Caring of the Fringe? Mediterranean Desertification between Peri-Urban Ecology and Socioeconomics. Sustainability 2022, 14, 1426. https://doi.org/10.3390/ su14031426

Academic Editors: Baojie He and Maria Rosa Trovato

Received: 2 November 2021

Accepted: 18 January 2022

Published: 26 January 2022

Publisher's Note: MDPI stays neutral with regard to jurisdictional claims in published maps and institutional affiliations.

Copyright: (C) 2022 by the authors. Licensee MDPI, Basel, Switzerland. This article is an open access article distributed under the terms and conditions of the Creative Commons Attribution (CC BY) license (https:// creativecommons.org/licenses/by/ $4.0 /)$.

\begin{abstract}
This commentary debates on the role of multiple socioeconomic drivers of fringe land degradation (including, but not limited to, population and social dynamics, economic polarization, and developmental policies), as a novel contribution to the desertification assessment in Southern European metropolitan regions, a recognized hotspot of desertification at the global scale. Expanding rapidly all over the world, metropolitan regions are a geographical space where land degradation drivers and processes assume typical relationships that require further research supporting dedicated policy strategies. To assure a better comprehension of the environmental-economic nexus at the base of land degradation in peri-urban areas, we provided a classification of relevant socioeconomic and territorial dimensions in both macro-scale and micro-scale degradation processes. We also identified the related (contextual) factors that determine an increased risk of desertification in metropolitan regions. Micro-scale factors, such as agricultural prices and off-farm employment, reflect some potential causes of fringe land degradation, with a mostly local and on-site role. Technological change, agricultural prices, and household income influence land vulnerability, but their impact on fringe land degradation was less investigated and supposed to be quite moderate in most cases. Macro-scale factors such as population density, rural poverty, and environmental policies-being extensively studied on a qualitative base-were taken as important drivers of fringe land degradation, although their impact still remains undefined. Regional disparities in land resource distribution, rural poverty, and unsustainable management of environmental resources like soil and water were indirect consequences of land degradation in peri-urban districts. Based on a comparative review of theoretical and empirical findings, strategies mitigating degradation of fringe land and reducing desertification risk in potentially affected metropolitan regions were finally discussed for the Northern Mediterranean basin and generalized to other socioeconomic contexts.
\end{abstract}

Keywords: land degradation; economic system; local development; macro-scale drivers; micro-scale drivers; southern Europe

\section{Introduction}

Economic re-organization of regions and countries implies changes in land resource availability, sometimes altering ecosystem quality and biodiversity [1-3]. Earlier studies have recognized economic uncertainty and ecological risk as key factors at the base of land degradation processes that involve group social change, local cultures, and policy action [4-6]. Biophysical and anthropogenic factors at the base of ecosystem changes stimulate an increasing attention of both theoretical and applied science to land degradation [7-9]. 
Both approaches are oriented toward a better comprehension of the consequences of ecosystem degradation on societies and economic systems [10,11].

Wealthier economies underwent a rapid expansion over the last century [12-14]. A more or less considerable part of this development was achieved at the expenses of ecological quality, ecosystem functioning, landscape integrity, and biodiversity stock [15-17]. Economic growth, social inequality, and their relations with soil resources and land quality at large [18-20] provide examples of the interplay between proximate causes and direct factors associated with desertification risk $[7,21,22]$. The broad debate on sustainable development-de facto linked with desertification risk - is in turn embedded in the analysis of complex interactions between biophysical and socioeconomic dimensions of change $[9,23,24]$.

As a possible departure from sustainable growth paths [25], land degradation in Mediterranean Europe was reflective of the continuous interplay among environmental, economic, and social systems - based on both proximate causes and underlying dimensions [26-28]. Multiple definitions of land degradation were proposed on the base of landscape characters, geographical area, time horizon, spatial scale, and socioeconomic contexts [29]. Despite the multiplicity of desertification notions inherent in recent literature [30], the most widely accepted definition is the one given by United Nation Convention to Combat Desertification (UNCCD) in 1977, implying 'land degradation in arid, semi-arid and dry sub-humid areas resulting from various factors, including climatic variations and human activities' [31].

Earlier studies stated that land degradation in the last century has increasingly spread throughout moderately dry regions nearly everywhere, negatively affecting the functioning of advanced economies more seriously than before [32]. Although landscapes show intrinsic transformations that encompass some (latent) forms of natural degradation [33], the ecosystem ability to recover may balance such transformations [34]. However, human pressure can be more intense and prevent the natural ability of ecosystems to recover, generating net degradation [35]. In these regards, human factors are intended as key drivers of land degradation in Mediterranean-type ecosystems [24].

Especially in official documents released from the UNCCD, land degradation was depicted, for a long time, as a 'rural' issue affecting areas that display a development gap with the strongest regions of the 'global north' [17]. The UNCCD Annex IV—specifically designed for the Mediterranean basin-highlights the dual development of central locations and marginal regions, focusing on the vulnerability of agro-forest ecosystems to climate change and anthropogenic impacts [10]. However, less attention was devoted on global processes of peri-urbanization and the intrinsic linkage with land degradation [36].

Being not exquisitely associated with rural development [37], the present study assumes land degradation in a 'peri-urbanized world' as a global issue that requires different responses for strictly rural regions and peri-urban areas [38] and justifies further studies on the latent nexus between land degradation and peri-urbanization [39]. Despite periurbanization not being a very recent process in advanced economies, the effects of climate warming, soil resource depletion, natural vegetation degradation, and rising human pressure in peri-urban areas manifested more recently with considerable intensity and low predictability [40]. Southern Europe, a region with increasing risk of land degradation and massive peri-urbanization and soil consumption since the early 1970s [39], seems a representative example of both dynamics [41]. One of the most representative and iconographic images of such issue is reported in Figure 1. This picture was realized and used for environmental awareness purposes by the Municipal Agency of Water Management of Barcelona, Spain. The image links intuitively the dynamic theme of urban growth (depicted with a compact settlement in Barcelona) with the dynamic issue of a desert, creating a particularly effective visual representation of the main topic of the present commentary. 


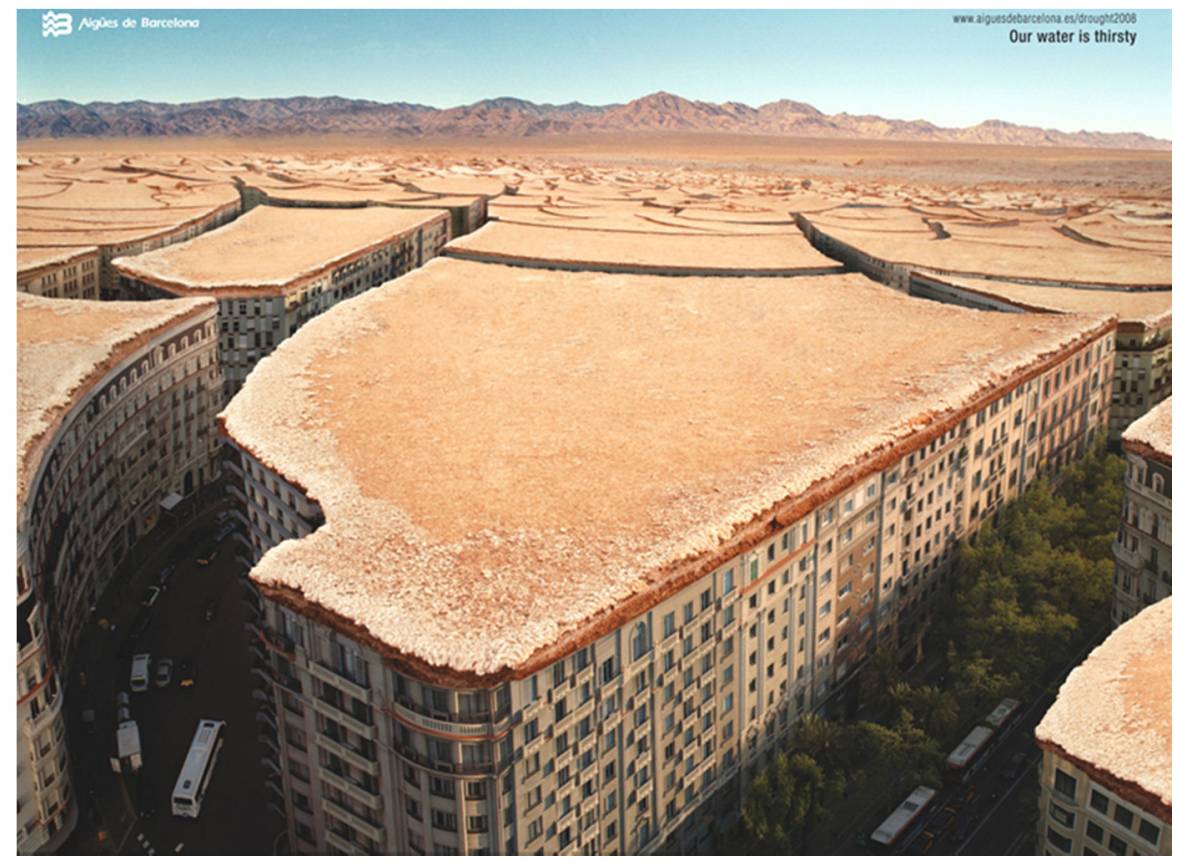

Figure 1. An iconographic representation of the 'urban desert' in a visual image used within environmental education programs in Catalonia, Spain (Source: Aigues de Barcelona).

Based on these premises, our study provides, likely for the first time in the recent literature, a brief review of the role of distinctive ecological processes and the related socioeconomic factors as potential drivers of land degradation in peri-urban areas of Southern Europe, as a result of spatial disparities, social inequalities, and economic polarization [42]. More specifically, we identify and briefly discuss-with a holistic perspective-multidimensional phenomena at the base of land degradation in the Mediterranean basin, a world hotspot for desertification [43]. This commentary was based on a literature review evaluating the consistency of established knowledge on the specific Mediterranean context and emphasizing (i) the socioeconomic processes that shape land degradation, (ii) the ecological impact of land degradation, (iii) the (positive and negative) implications on local communities, and (iv) formal/informal responses that societies can implement to contrast desertification risk [44].

While peri-urbanization is not a completely new process [45], what is rather new-and deserving of particular attention in positive approaches-is the dynamic association between land degradation, climate warming, and rising human pressure in fringe districts, which was more and more severe over the last two-three decades [46]. Dealing with socio-environmental contexts under rapid changes in fringe districts [47], our paper documents the importance of identifying (and continuous monitoring) land degradation hotspots in peri-urban regions as effective policy targets [48]. In this perspective, a commentary illustrating a brief review of recent literature and reorienting the debate on the socio-environmental role of land degradation in peri-urban fringes is appropriate in both environmental studies and regional planning.

Based on the novelty of the issue at stake, and the narrative/illustrative aim of the study, our article follows a structure typical of a commentary. Section 2 summarizes trends toward peri-urbanization in Europe and, more specifically, in the Northern Mediterranean basin. Some specific information and data were derived from analysis of official statistics and maps made available from Eurostat and the European Environment Agency. Section 3 delineates a logical framework aimed at investigating the ecological processes and the contextual drivers of land degradation in peri-urban areas. The assumptions in this chapter extensively benefited from a literature review based on extensive searches on scientific references' databases—namely Google Scholar-using keywords such as 'land degradation', 'desertification', 'peri-urban areas', and 'metropolitan regions'. References' search was 
not temporally limited. Section 4 identifies and discusses the main processes of land degradation, highlighting the importance of models and empirical approaches that clarify the interaction between multiple drivers of land depletion along urban fringes. Section 5 reviews (formal and informal) strategies and candidate actions mitigating fringe land degradation in socioeconomic contexts typical of Mediterranean Europe. Discussion in both Sections 4 and 5 benefited from the extensive literature review used to delineate the logical framework in Section 3. Finally, Section 6 concludes this work delineating a new interpretation of the environment-economy nexus responsible for fringe land degradation, generalizing policy implications to broader socioeconomic contexts.

\section{Peri-Urbanization in Southern Europe}

Increased accessibility, agglomeration factors, late industrialization, decentralized development processes, tourism specialization, and more recently, 'counter-urbanization', which is fueling a short-range population mobility from urban areas, are the main drivers of settlement expansion into rural areas, exerting an indirect impact on land degradation $[45,49,50]$. Following a long phase of radio-centric and compact urban expansion since World War II, an intense peri-urbanization in southern Europe took place in the 1960s and, more evidently, in the 1970s [39]. In this context, soil consumption became one of the most relevant aspects of land degradation in advanced countries where a large part of rural territories underwent peri-urbanization [36]. This phenomenon was particularly intense in the advanced economies of the Northern Mediterranean basin and led to a progressive consumption of fertile soils in the 1980s and the 1990s [51]. Recent initiatives of environmental monitoring at the continental scale in Europe (including the Global Monitoring and Environmental Surveillance (GMES) Copernicus Land program based on extensive use of satellite imagery and Geographic Information System tools) revealed a particularly evident dispersion of residential settlements around major cities in the Mediterranean region, as a response to land speculation, economic stimuli, changes in lifestyles, and commuting. The two examples depicted in Figure 2 (Rome and Lisbon) are representative of originally compact cities evolving rapidly toward sprawl. Similarly with these examples, metropolitan regions around central cities were demonstrated to include the majority of dispersed, discontinuous, and low-density settlements in Southern European countries [52].
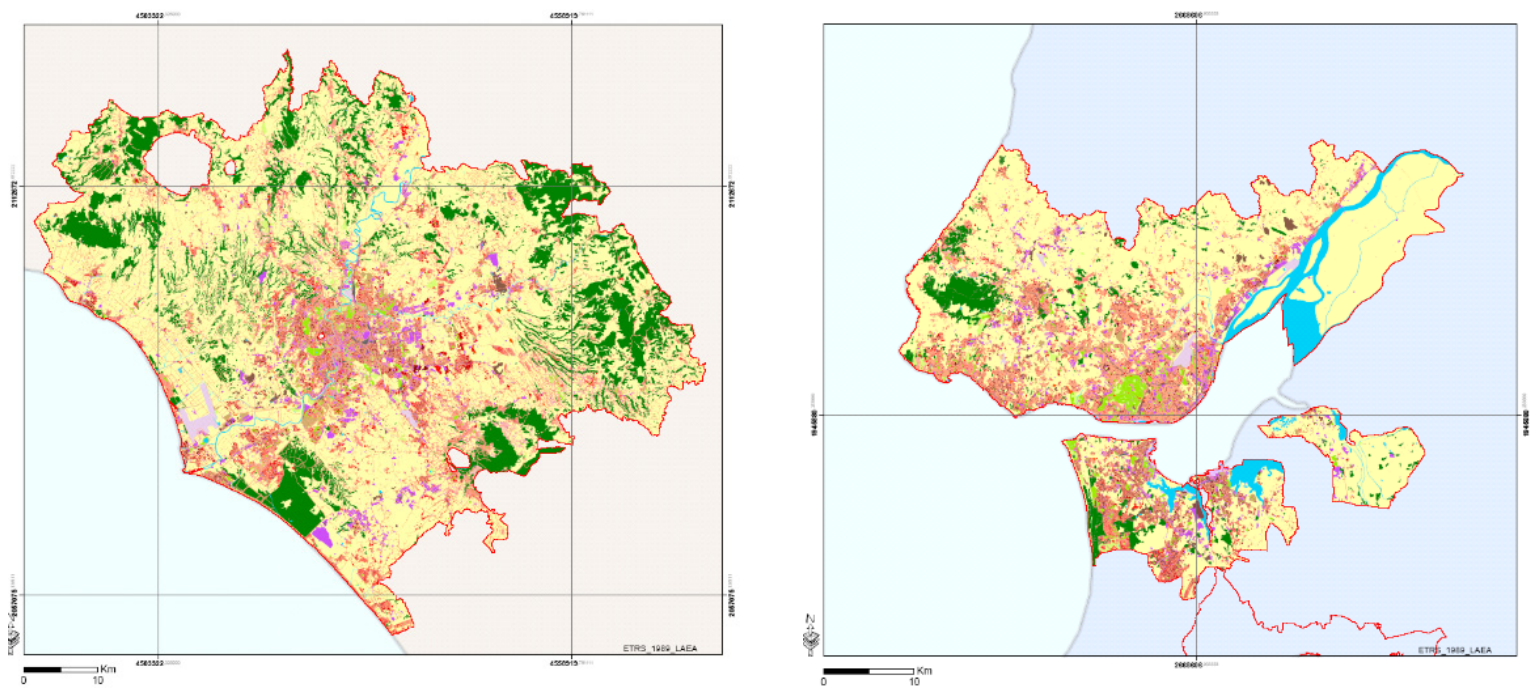

Figure 2. Dispersed urban morphologies in Southern Europe; examples from land-use maps of Rome (left) and Lisbon (right). Maps derived from Land Copernicus Urban Atlas (disseminated by European Environment Agency within the Global Monitoring and Environmental Surveillance (GMES) initiative) indicate urban fabric with red colors; a less intense red indicate discontinuous and low-density settlements (Source: own elaboration on Urban Atlas maps). 
Although Mediterranean regions were known as the most compact and dense settlement models in the European continent [53], such morphological features were progressively lost [42] as a result of the continuous interplay of global and local (economic) forces. A comparative analysis of trends over time in independent indicators such as settlement area in total landscape and per-capita built-up area clearly demonstrates such processes (Table 1). On average, a transition toward dispersed settlements in peri-urban spaces was particularly evident in southern European countries [25], in respect with the dynamics observed in Western, Northern, and Central Europe [39], although with intrinsic differences across countries that may reveal the importance of local contexts and the differential action of key drivers of change [54]. Although the major countries in Europe (Germany, France and, in part, Italy) showed a particularly high percent share of settlements in total landscape (values largely above the European average), Mediterranean countries such as Greece, Spain and, in part, Portugal, displayed a high (or moderately high) increase over time in settlement area (2009-2018), in common with some northern European countries (e.g., Sweden, Estonia). Per-capita built-up area, an indicator of land-use efficiency and urban sprawl, classifies settlements in Mediterranean European countries as particularly compact (low per-capita built-up area), on average [55]. However, the per-capita amount of built-up land increased rapidly in these countries, especially in Greece, Portugal and, partly, Italy, with per cent rates above the European average [42]. Taken together, these results delineate a moderate transformation of metropolitan landscapes in Southern Europe moving from compact and dense settlements to a more sprawled, low-density urban fabric, in line with a transition already observed in other European countries [53]. These building dynamics, referring to a crisis/early post-crisis phase, add to a long urbanization-suburbanization cycle. Population expansion determined massive soil consumption and urban growth into cropland between the early 1960s and the late 2000s [39,45,50].

Table 1. Selected indicators of urban expansion in European countries by year (source: authors' elaboration on Eurostat data).

\begin{tabular}{|c|c|c|c|c|c|c|c|c|c|c|c|}
\hline \multirow{2}{*}{ Country } & \multicolumn{5}{|c|}{ Settlement Area in Total Land (\%) } & \multirow{2}{*}{ Country } & \multicolumn{5}{|c|}{ Per-Capita Built-Up Area $\left(\mathrm{m}^{2}\right)$} \\
\hline & 2009 & 2012 & 2015 & 2018 & Change (\%) & & 2009 & 2012 & 2015 & 2018 & Change (\%) \\
\hline Latvia & 3.2 & 3.5 & 4.0 & 3.8 & 2.1 & Netherlands & 431 & 457 & 472 & 457 & 0.7 \\
\hline Estonia & 3.4 & 3.8 & 4.5 & 4.3 & 2.9 & Italy & 440 & 459 & 472 & 484 & 1.1 \\
\hline Finland & 3.4 & 3.8 & 4.0 & 4.0 & 2.0 & Un. Kingdom & 442 & 430 & 431 & 427 & -0.4 \\
\hline Sweden & 3.6 & 4.4 & 5.1 & 5.0 & 4.3 & Germany & 527 & 553 & 565 & 587 & 1.3 \\
\hline Greece & 4.4 & 4.8 & 5.2 & 5.8 & 3.5 & Poland & 532 & 594 & 624 & 634 & 2.1 \\
\hline Lithuania & 4.4 & 3.7 & 4.7 & 4.7 & 0.8 & Slovakia & 538 & 515 & 536 & 632 & 1.9 \\
\hline Spain & 4.9 & 5.0 & 5.1 & 5.4 & 1.1 & Luxembourg & 543 & 628 & 512 & 565 & 0.5 \\
\hline Slovenia & 5.8 & 5.8 & 6.2 & 6.4 & 1.1 & Spain & 562 & 556 & 573 & 578 & 0.3 \\
\hline Slovakia & 5.9 & 5.7 & 5.9 & 7.0 & 2.1 & Greece & 562 & 577 & 628 & 710 & 2.9 \\
\hline Ireland & 6.0 & 6.7 & 6.5 & 6.7 & 1.3 & Belgium & 573 & 538 & 582 & 584 & 0.2 \\
\hline Poland & 6.5 & 7.2 & 7.6 & 7.7 & 2.1 & Slovenia & 579 & 571 & 609 & 625 & 0.9 \\
\hline Austria & 6.5 & 7.0 & 7.2 & 7.8 & 2.2 & Portugal & 588 & 602 & 621 & 689 & 1.9 \\
\hline Portugal & 6.7 & 6.8 & 6.9 & 8.0 & 2.2 & European Union & 616 & 644 & 673 & 673 & 1.0 \\
\hline European Union & 7.2 & 7.6 & 7.9 & 8.2 & 1.5 & Czechia & 624 & 588 & 616 & 634 & 0.2 \\
\hline Hungary & 7.6 & 7.3 & 7.5 & 8.5 & 1.3 & Austria & 654 & 695 & 704 & 740 & 1.5 \\
\hline Czechia & 8.3 & 7.8 & 8.2 & 8.5 & 0.3 & Hungary & 703 & 681 & 704 & 812 & 1.7 \\
\hline Italy & 8.6 & 9.1 & 9.5 & 9.7 & 1.4 & France & 834 & 841 & 835 & 845 & 0.1 \\
\hline France & 9.6 & 9.8 & 9.8 & 10.3 & 0.8 & Lithuania & 899 & 804 & 1053 & 1091 & 2.4 \\
\hline Luxembourg & 10.4 & 12.9 & 11.2 & 13.1 & 2.9 & Ireland & 922 & 1016 & 961 & 973 & 0.6 \\
\hline Unit. Kingdom & 11.2 & 11.2 & 11.5 & 11.6 & 0.4 & Denmark & 970 & 1021 & 1052 & 1054 & 1.0 \\
\hline Germany & 12.1 & 12.4 & 12.9 & 13.6 & 1.4 & Latvia & 970 & 1127 & 1297 & 1276 & 3.5 \\
\hline Denmark & 12.4 & 13.2 & 13.9 & 14.2 & 1.6 & Estonia & 1164 & 1316 & 1541 & 1484 & 3.1 \\
\hline Netherlands & 19.1 & 20.5 & 21.4 & 21.0 & 1.1 & Sweden & 1718 & 2084 & 2344 & 2223 & 3.3 \\
\hline Belgium & 20.2 & 19.5 & 21.4 & 21.7 & 0.8 & Finland & 2137 & 2338 & 2459 & 2448 & 1.6 \\
\hline
\end{tabular}




\section{An Empirical Approach Identifying Drivers of Fringe Land Degradation}

To better qualify the relevant drivers of fringe land degradation in Mediterranean Europe, the studied soils have been frequently classified in three functional types (Figure 3): (i) 'strictly desertified' areas, mainly dryland with 'functional sterility' of soils; (ii) areas classified at risk of desertification, sometimes mixed with 'strictly desertified land', displaying ecological traits similar with desertified land, but with specific factors (e.g., vegetation cover, land-use, climate) mitigating land degradation; and finally, (iii) vulnerable (or sensitive) areas where land degradation is active locally, having partially lost their ecological and economic potential, and thus being considered at a very early stage of desertification [56-58].
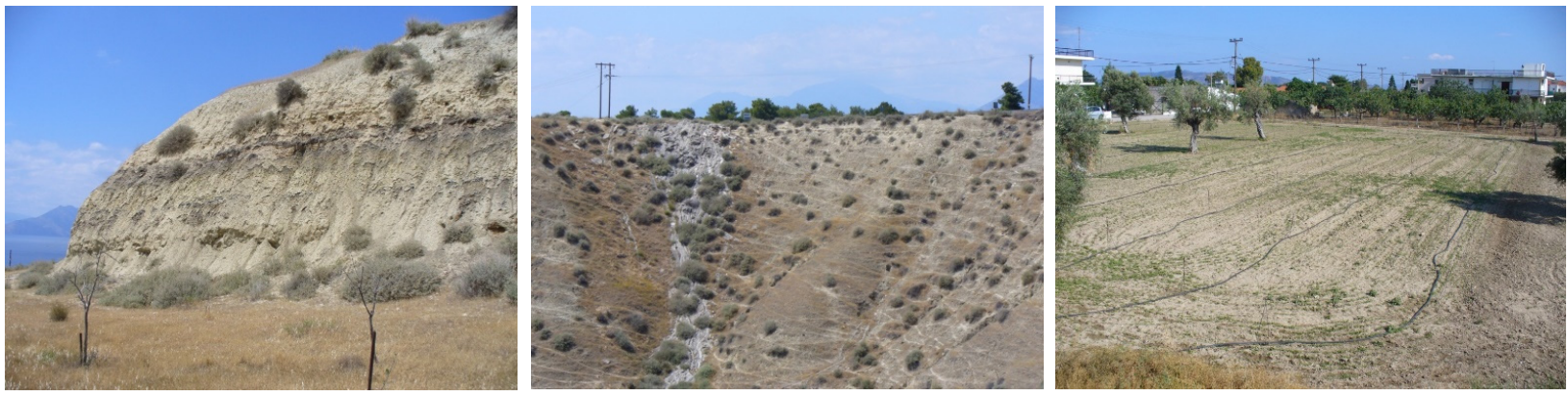

Figure 3. Examples of fringe land following the classification in three functional types (left: type (i) dryland, middle: type (ii) mixed land, right: type (iii) sensitive land (see the extensive description in the text above); source: authors' photographic archive.

The spatial distribution of these soil classes in peri-urban spaces of Southern Europe is largely unknown [59]. Recent literature has occasionally documented how land degradation can be interpreted assuming that it depends, distinctively at the local and regional scale, on the interaction between social, economic, environmental, cultural, political, and institutional factors [60]. A flow-chart illustrating some relevant examples is provided in Figure 4.

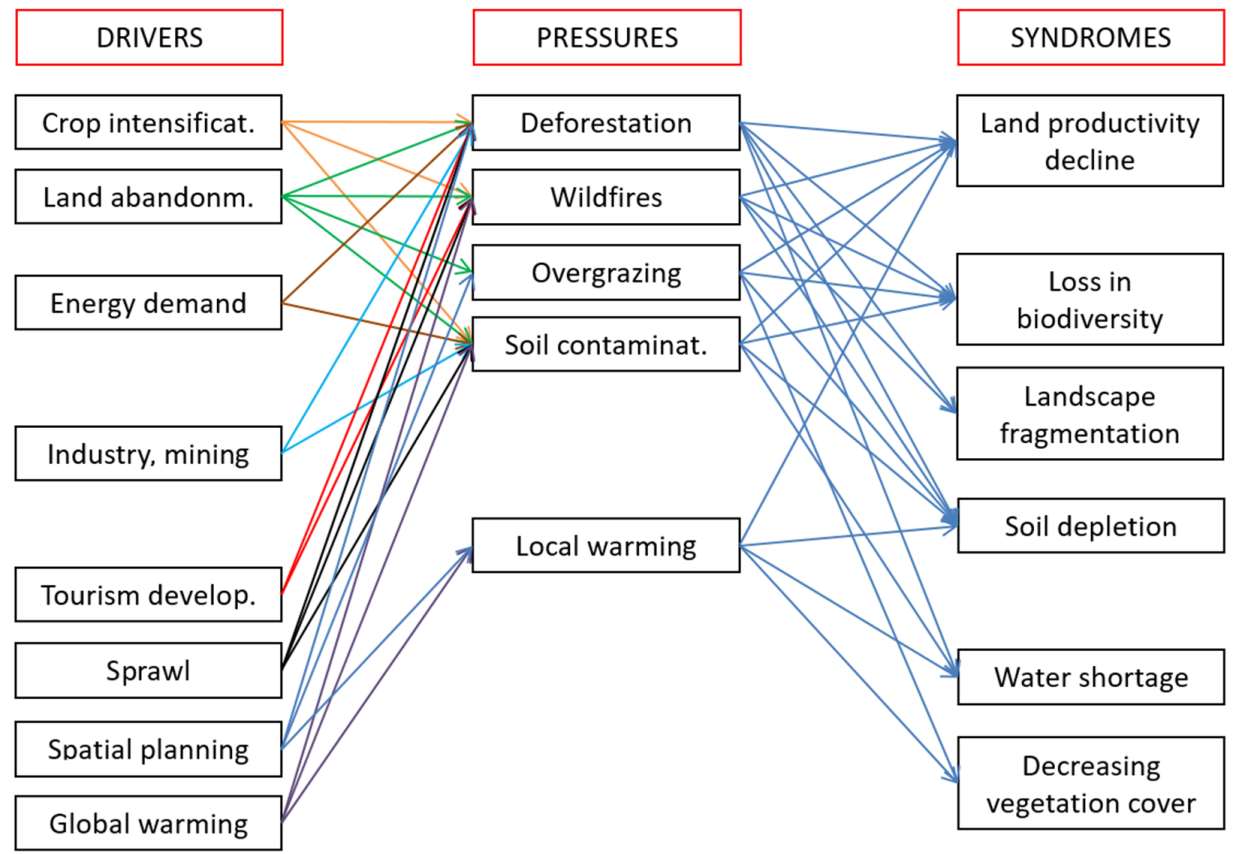

Figure 4. A flow-chart depicting examples of socioeconomic processes possibly leading to land degradation in peri-urban districts, including the cases illustrated in Figure 3; source: authors' own elaboration. 
In this view, investigation of land degradation trends in peri-urban areas should more carefully consider the relationship between the 'urban' socioeconomic dimension and the 'regional' settlement structure [61]. In other words, diversified phenomena at the base of land vulnerability to degradation should be discussed in light of demographic, economic, and environmental processes underlying metropolitan structure [62]. We assume peri-urban spaces-understood as morphological and functional structures-are not self-sufficient in sustainable development because of the intense (and increasing) human pressure, and thus require environmental protection strategies against land consumption and soil depletion [63].

The operational framework proposed in this commentary classifies land degradation drivers into macro-scale and micro-scale factors [6]. This allows a refined understanding of socio-environmental processes from multiple, disciplinary perspectives [64] and suggests approaches suitable for permanent monitoring and modeling [34,50,65]. The starting point of this approach identifies the economic agents at the base of land degradation [66]. Agents' decisions were better understood when evaluating their own characteristics, such as background, preferences, and resources [67]. Broader forces shape agents' characteristics and decision variables [68]. These factors influence agents' decisions through diversified channels, among which local markets, new technologies and information, infrastructures, institutions, and local communities play a key role [69-71].

\section{Individual Processes and Contextual Factors of Fringe Land Degradation}

\subsection{Macro-Scale Factors}

Identification of macro-scale factors of land degradation depends on the difficulty to assess their intrinsic relationship [17]. Macroeconomic dimensions of change affect socioenvironmental decisions through complex paths of change, and many of these linkages are indirect [15]. Investigating such linkages requires data that often do not exist or are of bad quality, because data availability is restricted to a partial country coverage or inappropriate resolution scale $[16,72,73]$. In the following paragraphs, we summarize the main factors assumed as relevant in shaping land degradation processes in peri-urban areas.

\subsubsection{Population Growth}

Land degradation is associated with increasing population and a rising demand for buildable land, food, and fibers [1]. Growing population in suburban locations affect job markets, possibly inducing technological progress and institutional changes [74]. This may contribute to reduce pressure on neighboring croplands and forests [75], while determining on-site soil consumption along peri-urban fringes [76]. Although earlier studies have documented a positive correlation between population growth and land degradation, these findings remain often mixed and fragmented [77]. A comprehensive understanding of this issue will benefit from a comparative analysis making explicit the spatial relationship between population increase and land degradation in representative cases [60]. At the same time, population mobility typical of metropolitan regions lead to a discrepancy between carrying capacity and demographic density in affected areas [54]. Such movements contribute to determine environmentally unstable conditions and potentially threatening soils and landscapes [45]. It was also demonstrated how a high population density does not necessarily trigger land degradation, being more dependent on the combination of various aspects that include land-use and settlement patterns (compact vs. dispersed), economic conditions, and land management practices, which are particularly evident in peri-urban areas [24]. Suburban population growth added to the negative impact of (global and local) warming (driven by both climate change and urbanization) leading sometimes to drastic conditions [36] that are particularly evident in fringe districts [46].

\subsubsection{Human Pressure on Land}

Although population growth may have (mostly indirect) consequences on land degradation, human pressure derived from non-demographic pressures is likely more important, 
as a result of practices such as relocation of people to the sea coastal borders because of tourism development, and concentration of industrial activities in fringe districts [58,76,78]. These phenomena negatively impact the environmental quality in suburban districts, because civil, industrial, and agricultural land-use compete for water and soil resources [79]. In the short term, tourism concentration is expected to influence urban sprawl in more accessible peri-urban districts, triggering land fragmentation in ecologically fragile areas, inducing infrastructural development [80]. In the long term, tourism development stimulates more dense settlement growth and may consume fertile soils suitable for agriculture [53] around cities and in economically dynamic, flat districts [81]. However, tourism development may indirectly strengthen environmental awareness stimulating indirect responses to land degradation [44], with an increasing hedonic value of natural heritage in sparse sites [38].

\subsubsection{Agriculture}

Crop intensification is another example of human pressure on fringe land [58]. Overstocking, over-cultivation, and deforestation (directly or indirectly) induced by urbanization gave additional stimuli to land degradation in such conditions [72]. The nature of property rights on land [12], the governing institutions [44], as well as cultural and family traditions [69], may in turn impact these dynamics either positively or negatively, although their influence was assumed to be less important in peri-urban districts than in strictly rural areas [30]. A low soil productivity in fringe districts affect yield fluctuations, also due to reduced precipitations and prolonged droughts [82] - a consequence of heat waves typical of urban environments [83]. Such dynamics may discourage topical investments [84] and appropriate conservation practices [85] in fringe land, determining a depreciation of suitable land for agriculture and exposing them to increased building speculation [86]. Some examples of agricultural dynamics possibly leading to degradation of fringe Mediterranean land are illustrated in Figure 5, evidencing, from left to right, farm extensivation and land take by isolated buildings [51], greenhouse development in districts experiencing intense residential sprawl [39], as well as crop abandonment in fertile areas [87].
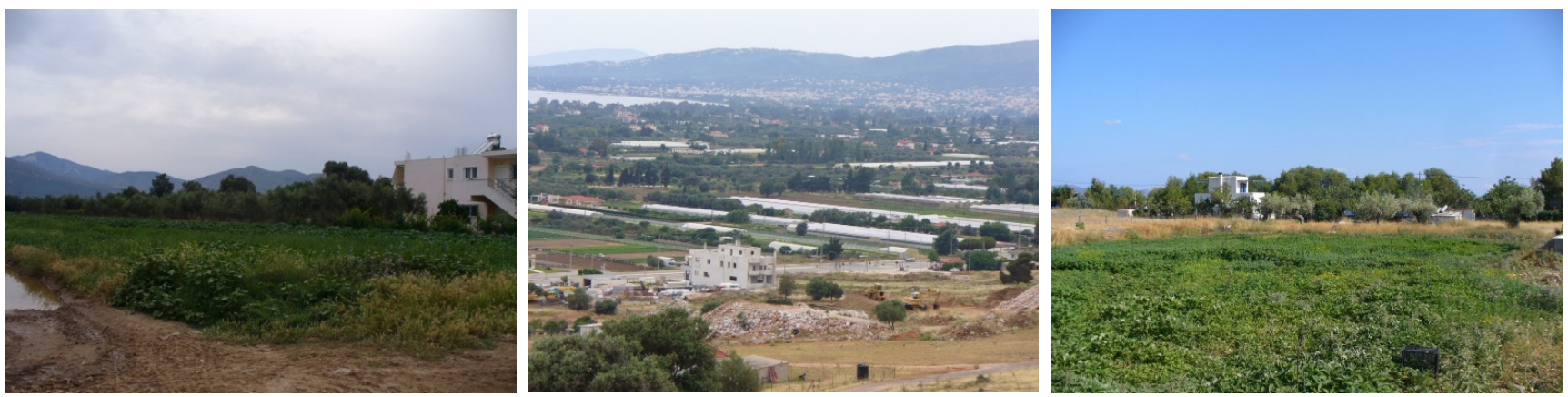

Figure 5. Examples of agricultural dynamics leading to land degradation in fringe Mediterranean land (left: farm extensivation and land take from isolated buildings; middle: greenhouse development and urban sprawl; right: crop abandonment in fertile areas); source: authors' photographic archive.

Policies addressing agricultural development in peri-urban regions should therefore trigger a vicious circle producing a distortion that may enhance the spatial polarization in 'favorable' and 'less favorable' districts, most severely affected by physical deterioration and monetary depletion of land resources [2]. While remaining highly dynamic and wealthy [88], peri-urban districts have more recently experienced a downward spiral degrading natural resources and creating unsustainable conditions for future development [89]. In this perspective, the abandonment of traditional agricultural systems in suburban districts was largely documented as, together, cause and consequence of land degradation [54]. 


\subsubsection{Socioeconomic Development}

A focus on environmental-economic transitions in fringe districts is appropriate to delineate the intrinsic mechanisms at the base of complex development paths in metropolitan regions [46]. A higher (hedonic) value of fringe landscapes, and the expanded state capacity to enforce land protection, are possible examples of such dynamics $[14,34,75]$. At the same time, both wealth accumulation and poverty have been seen as causal factors and consequences of land degradation [47], being in turn associated with local impacts of climate warming, e.g., precipitation reduction and heat waves leading to water shortage and droughts [66]. In rural contexts, poverty was demonstrated to be a socioeconomic condition associated with recurrent drought, soil degradation, and desertification risk [90]. In economically disadvantaged dry regions of Mediterranean Europe, it is assumed that local communities are sometimes characterized by vulnerability to natural disasters and limited access to a variety of public or private (upper-level) goods and resources [16,91]. Such background conditions corroborate the idea that poverty is associated with both economic marginality and land degradation [92]. Institutional mechanisms, governance frameworks, policy measures, and local markets can exacerbate or mitigate such relationship [62], although further evidence is needed to document the intrinsic impact of mitigation measures [51].

On the contrary, in peri-urban areas, the mechanisms through which poverty shapes land degradation have been rarely addressed [93], and comparative investigation e.g., on the impact of urban unemployment on peri-urban farming is particularly appropriate to ascertain such dynamics [94]. For instance, [90] documented the progressive reoccupation of fertile and productive, but partially abandoned, peri-urban land for farming driven by 'working poors' and young/middle-age urban employees losing their job because of the 2007 crisis in Athens, Greece. Since this farming type is substantially extensive and environmentally low impact, the final outcome of the process was the revitalization of farm activities and an indirect containment of speculative pressures on land.

\subsection{Micro-Scale Factors}

The adoption of unsustainable practices in agriculture-and possibly in other economic sectors-was demonstrated to be a factor of land degradation in southern Europe [66], although specific evidence on mechanisms dealing with fringe land degradation is lacking. Assuming both households and companies act as a source of change [37], investigating the micro-scale causes of land degradation will benefit from a comparative investigation of (i) prices of agricultural products and inputs, (ii) property regimes, and (iii) changes in agricultural technology [15], among others. These transformative processes may be considered as possible engine of soil degradation in metropolitan regions, alone or more frequently, in synergy with other factors of change.

\subsubsection{Agricultural Prices}

Higher prices for agricultural products stimulate land over-exploitation, possibly reflected in soil degradation, and push additional land into production [72]. This scheme, originally adopted to explaining rural development in emerging countries [14], can also be adopted for land degradation analysis in peri-urban regions of advanced economies, when a persistent conflict for land exists between agriculture, industry, and residential settlements [69]. In some cases, it was demonstrated how peri-urban farmers exhibit a preference for subsistence-type farming and may respond to higher prices by reducing the surface of cultivated land [95], although there is no specific evidence for this behavior in peri-urban farms [86], and the possible factors at the base of such transformations can be multiple and difficult to ascertain. Moreover, how changes in agricultural input prices influence land degradation may lead to unclear evidence, not only in metropolitan regions, but also in the 'rural' world [29]. For instance, higher fertilizer prices lead farmers to adopt more extensive production systems that use more land and less fertilizers [26]. However, the higher costs associated with increased fertilizers make the agriculture less 
profitable [8], with indirect effects on both crop intensification and extensivation [44]. Long-term dynamics of agricultural prices-taken as a relevant economic impulse of land degradation [51]—need further investigation.

\subsubsection{Land Prices and Property Regimes}

Land prices are directly dependent on technological progress and infrastructures that will make cultivation profitable in the coming future, in turn incorporating short-term prospects of such improvements [12]. At the same time, land prices in fringe districts may not reflect the agricultural potential but rather speculation that purchasers will profit from selling the land at a given date in the future [68]. Such dynamics were occasionally documented in fringe areas surrounding large Mediterranean cities-whose territory is structurally sensitive to land degradation due to climate aridity, poor soils, and vegetation cover [39]. However, these processes could be negligible (or at least, less important) for land degradation in developed economies where property regimes are more precisely defined [25]. Because of mixed research findings [51], there is still scope for investigating the relationship between land prices and unsustainable soil management in fringe contexts exposed to soil degradation [14,33,75]. Within metropolitan regions, since farms on rent land were sometimes increasing in number, size, and environmental impact [86], this process can be relevant for fringe land protection and strategies mitigating degradation of peri-urban soils $[40,82,96]$.

\subsubsection{The Impact of Technological Change}

Technology has both a direct impact on farmers' behavior and an indirect effect resulting from its impact on product and factor prices [3]. Technological change that pushes yields without significantly altering labor or capital requirements are expected to impact land degradation via crop intensification [72]. Degradation intensity is assumed to be higher if technological changes are labor- or capital-saving [97], suggesting that agricultural research and policies designed to preserve land quality should focus on promoting profitable technologies that are labor and capital-intensive [84]. Technological inputs have also indirect effects on production, labor, and factor markets [92]. Similarly, capital-intensive technologies might have the same effect when farmers have limited access to capital [98]. In both perspectives, empirical evidence is still limited for the 'rural' world, and a specific rationale for peri-urban regions is completely lacking [89].

\subsection{A Summary Perspective}

While empirical studies on macro-economic —and especially micro-economic-factors of land degradation are generally restricted in advanced economies, metropolitan areas are considered a representative 'laboratory' of the economic interactions among the possible agents (directly or indirectly) involved in land degradation [46,96,99]. An example of such interactions, generating both positive and negative impacts on land degradation, is reported in Figure 6 and deals with constraints and opportunities faced by peri-urban farmers. This framework may delineate a sort of 'multidisciplinary arena' [46,96,97,99], whose intimate comprehension needs integration of empirical approaches, comparative fieldwork, and in-depth analysis of case studies providing solid positive and normative foundations.

Application of such integrated frameworks to representative case studies in France [86], Spain [87], and Italy [51] confirms the appropriateness of a 'constraints vs. opportunities' thinking when evaluating the (mixed, both positive and negative) role of peri-urban farmers as land degradation agents. With this perspective in mind, our study stimulates further investigation on agronomic practices specifically run-in peri-urban areas and aimed at testing the validity of the interpretative framework proposed here. This research will also clarify some working assumptions that are still underexplored in advanced economies [46]. Examples of formal and informal practices partly or fully in line with sustainable management of peri-urban soils and high-quality landscape conservation are reported in Figure 7. Examples include both high- and low-productivity Mediterranean landscapes character- 
ized by climate dryness and human pressure where, however, vegetation cover, agronomic practices, and local development coexist limiting the negative externalities of economic activities on environmental quality, thanks to the key role of local farmers.

$\begin{gathered}\text { Constraints } \\ \text { Price of land }\end{gathered}$
$\begin{gathered}\text { Opportunities } \\ \text { Changes in land planning } \\ \text { Insecurity in land tenure } \\ \text { New social demand on farming } \\ \text { Demand for local food }\end{gathered}$
Darmers react to structural changes, acting
as knowledgeable agents of the urban farming context
taking into account scales:

Figure 6. Constraints and opportunities faced by peri-urban farmers: a logical scheme of socioeconomic dynamics shaping land degradation in fringe Mediterranean land (source: authors' own elaboration).
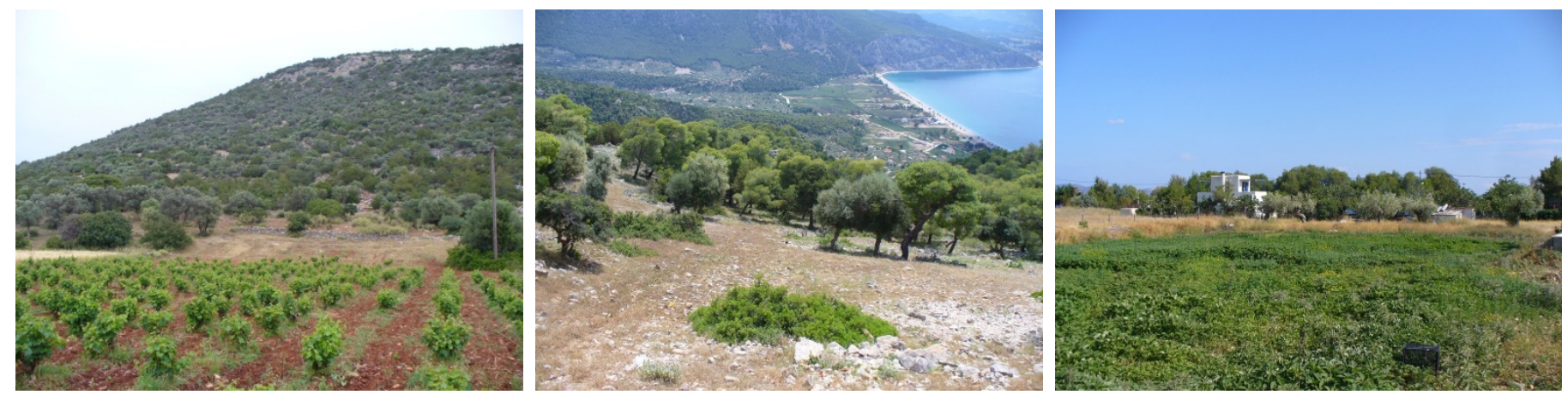

Figure 7. Constraints and opportunities faced by peri-urban farmers: a logical scheme of socioeconomic dynamics shaping land degradation in fringe Mediterranean land (source: authors' photographic archive).

\section{Discussion}

Reconnecting socioeconomic impacts on a regional scale with the ecological-territorial dynamics on a local scale certainly contributes to an enriched knowledge of local communities, outlining how a study of differences based on assumptions of non-linearity and complex thinking is a key to understanding socio-environmental trends in Southern Europe. Although urbanization has been related to economic development and demographic change, heterogeneous patterns and processes of growth and regional change reflect the uneven distribution of urban development, the subtle impact of demographic dynamics, and the implications for land resource management and environmental sustainability. Differences in patterns of urban growth and change in a paradigmatic region such as Mediterranean Europe-often masked by official statistics indicating a sharp increase in metropolitan population-reflect regional divisions in socio-demographic, economic and environmental dimensions.

The present commentary discusses the spatio-temporal evolution of land degradation, a global environmental issue with important socioeconomic implications, and its possible relationship with regional development processes $[11,25,100]$. The study documents how, after a prolonged urbanization phase across the Mediterranean basin, urban sprawl is still evident in the last decade, although with different intensities and spatial directions [46]. This high-impact morphology is more and more associated with the rising impact of climate warming and anthropogenic pressures on land quality and soil fertility in peri- 
urban areas [36]. Since heterogeneous processes of soil degradation complicate assessment and limit the development of efficient action plans [101], empirical findings from recent literature were analyzed here, integrating three disciplinary perspectives (environmental sustainability, regional economics, and geography, spatial planning). Results of such a review may delineate suitable mitigation strategies for degradation processes [20,22,102].

Earlier studies have intended land degradation as a particularly complex and composite phenomenon, documenting how different dimensions of the land resource base (e.g., soil, vegetation, climate) have changed for the worse because of mixed environmental and socioeconomic causes $[85,103,104]$. Theoretical and empirical research focusing on the socioeconomic factors that impact (or interact with) fringe land was consolidated in recent decades, despite bringing to mixed and partial results in most cases [10]. With this perspective in mind, peri-urban areas are sometimes assumed as a sort of 'laboratory' of land degradation [50], because of the interplay of a particularly wide range of climatic and human drivers, from local warming to on-site soil pollution, from land speculation for building to farm abandonment, from intensive construction to mining activities-usually concentrated in smaller areas than observed in the strictly 'rural' world [101].

\subsection{Coping with Degradation of Fringe Land: A Geo-Economic Perspective}

The generalized increase in the level of land vulnerability to degradation documented for several metropolitan regions in Mediterranean Europe indirectly reflects how the classical center-periphery model, based on mostly linear relationships among relevant drivers, was progressively losing strength $[36,39,58]$. More diluted and entropic relationships have taken place, as an intrinsic characteristic of polycentric settlement models taking place, more or less rapidly, in southern Europe [53]. What measure regional disparities affect the spatial distribution of vulnerable land [105] and the role of social inequality and economic polarization are still unclear [19]. Elements such as the nature of governing institutions, the persistence of cultural and family traditions at the local scale, and the nature of land property rights [44], further complicate the comprehension of net degradation processes over fringe land [50].

Based on these premises, it is assumed how a refined understanding of such relationships require a multidisciplinary approach [106]. The incompleteness of both theoretical and empirical knowledge depends on the fact that 'soft' sciences (economics, sociology, demography) have sometimes underestimated the role of local communities in containing (or triggering) degradation of fringe land [22,45], while planning has proposed indistinct views mechanistically applied to both rural and peri-urban areas. Studies carried out by agronomists, ecologists, and soil scientists, in turn focused on land degradation processes at a very detailed geographical scale [31], and may lose the 'holistic view' typical of a geo-economic analysis run at the appropriate spatial scale [77]. Such analyses involve the socioeconomic actors of land degradation (e.g., municipalities, economic districts, watershed authorities, provinces, and urban/metropolitan regions at large). In this perspective, fringe land degradation and the relationship with peri-urbanization, sprawl, and land-use change have been relatively poorly studied in the Mediterranean basin [54]. By developing a merely ecological approach [48], few studies have partially addressed (i) the role of land consumption, especially for agricultural use, (ii) the loss of semi-natural vegetation, (iii) the increasing risk of soil and groundwater salinisation, and (iv) the contribution of population density and urban growth in the level of land vulnerability [58]. However, there is certainly scope for an in-depth analysis of these phenomena from a different perspective, assuming the geo-economic approach as particularly appropriate for this investigation [71].

\subsection{Territorial Disparities and Land Degradation: From Research to Practice}

Supposing that territorial disparities reflect specific patterns of land vulnerability shaped by complex interactions among several socioeconomic and biophysical factors [6], the divergence in land vulnerability could increase over time along the metropolitan gradient due to worsening ecological conditions and increasing human pressure [32]. With 
crop intensification leading to soil compaction and salinization $[11,83,86]$, urbanization enhanced environmental disparities at the regional scale [8,24]. Notably, this process was also active at wider spatial scales [107]. The consequence of such dynamics could represent a sort of 'downward spiral' of environmental degradation [14], increasing territorial polarization due to an unbalanced distribution of land resources [108], and contributing to unsustainable paths of regional development $[75,79,81]$.

The center-periphery model represents a classical framework suitable to interpret socioeconomic disparities in a spatially explicit perspective [109], and can be proficiently applied to analysis of territorial imbalances in land resource that reflect spatially polarized processes of environmental degradation. Implications of the center-periphery relationship applied to land degradation drivers include (i) the consumption (or degradation) of fringe soils with high agricultural potential (e.g., soil fertility), (ii) the impoverishment of groundwater resources over metropolitan river basins due to water overexploitation for e.g., domestic use, and (iii) the abandonment of cultivated land in suburban areas with a consequent increase in marginal and unproductive land [31,40,107,110]. Rising wildfire severity at the expenses of agricultural and semi-natural buffer areas (Figure 8), concentration of tourism and industrial activities in both coastal and lowland districts around cities, and sprawl-induced land fragmentation reducing the connectivity among natural patches were documented factors of land degradation [32,53,62,79].

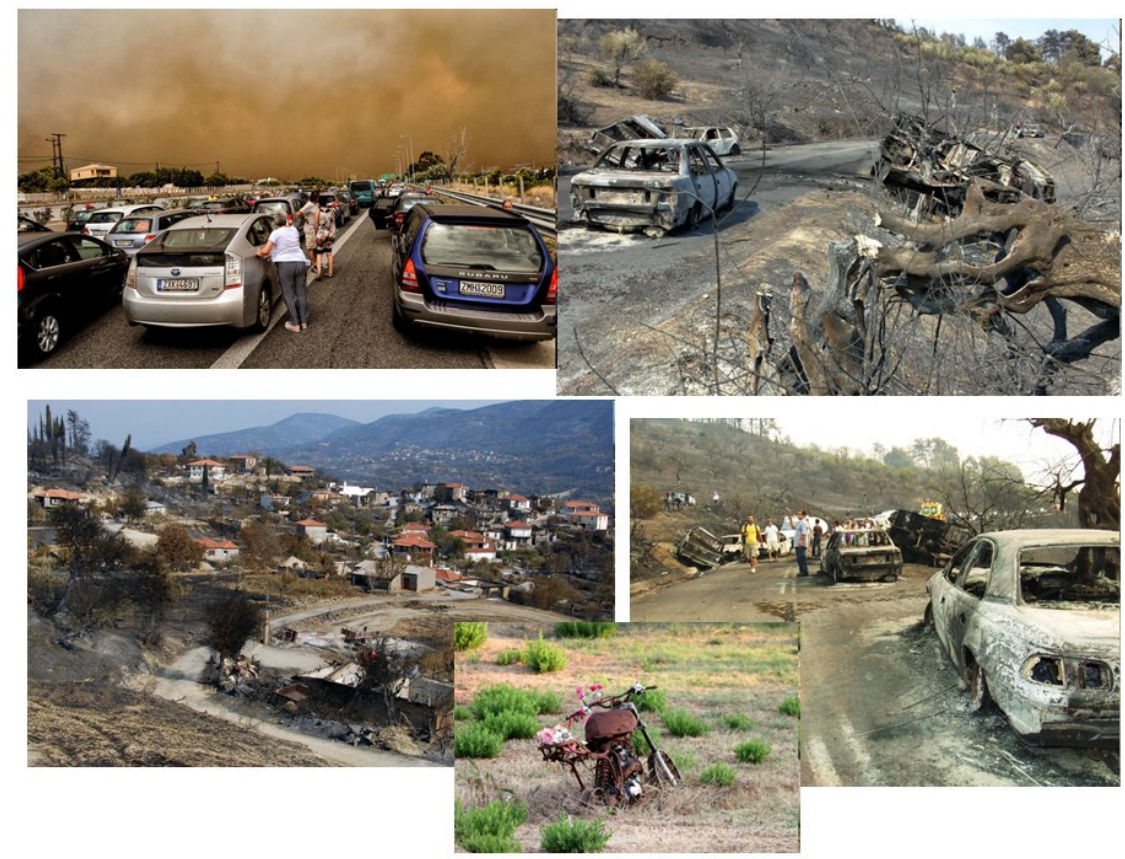

Figure 8. Selected images documenting the drastic wildfire events along Athens' fringe in 2018 producing many casualties and incalculable damages to settlements and landscapes (source: authors' own elaboration from materials courtesy provided by Prof. Anastasios Mavrakis).

As far as the policy dimension is concerned, land mitigation strategies in the Mediterranean basin are especially designed for (and applied to) strictly rural areas [44]. Coping with land degradation in mixed urban-rural regions needs operational tools and dedicated governing efforts that are specific to (rapidly changing) peri-urban spaces [55,111]. Taken as an effective policy target, land degradation hotspots, a well-known concept largely investigated in rural districts [58], should be more explicitly identified in peri-urban regions and their evolution continuously monitored over time [36]. Identification criteria can be derived from earlier studies or created ex-novo [48]. In such hotspots, measures aimed at mitigating land degradation should consider together the reduction in socioeconomic disparities and the target of environmental sustainability of economic productions [20]. Specific measures against land degradation should be also arranged as a function of the 
local level of land vulnerability [31]. Policies based on the degree of disturbance of each land unit may rationalize land conservation actions [9], contributing to reduce the risk of desertification in dry peri-urban regions $[8,40]$.

\section{Concluding Remarks: Rethinking Land Degradation as a Peri-Urban Issue}

The intimate linkage between degradation of fringe land and complex socioeconomic processes such as poverty, social stratification, economic competitiveness, and settlement growth in the Mediterranean basin [47], requires a comprehensive policy framework towards population decentralization, sustainable land management, and reduction in unwanted human pressures [10]. Mitigating land degradation in fringe districts cannot be separated from the issue of sustainable development in 'metropolitan drylands' [38]. Assuming the idea and practice of appropriation and use of land as socially constructed, soil productivity and land capacity, cultivations, land use, and sustainable development are reflective of human-nature interactions [68]. The specificity of land degradation processes in metropolitan regions should be debated in connection with the theoretical framework of sustainable development [53]. Technological change, the impact of credit markets, the mitigation of social conflicts for land resources, and the uncertain resilience of peri-urban systems, are topics that require further investigation [29]. Carrying out pilot studies that evaluate the impact of sustainable land management strategies, will definitely support the implementation of adaptive approaches mitigating fringe land degradation.

Author Contributions: Conceptualization, A.S. and A.M.; methodology, L.B.; software, M.C.; validation, G.Q. and R.S.; formal analysis, R.H.-C.-Z.; investigation, L.B.; resources, A.M.; data curation, M.C.; writing-original draft preparation, A.S. and L.B.; writing-review and editing, G.Q. and R.S.; visualization, A.M.; supervision, M.C.; project administration, R.H.-C.-Z.; funding acquisition, R.H.-C.-Z. All authors have read and agreed to the published version of the manuscript.

Funding: This research received no external funding.

Institutional Review Board Statement: Not applicable.

Informed Consent Statement: Not applicable.

Data Availability Statement: Data from official statistics and bibliographic analysis of scientific literature were used here.

Conflicts of Interest: The authors declare no conflict of interest.

\section{References}

1. Harte, J. Human population as a dynamic factor in environmental degradation. Popul. Environ. 2007, 28, 223-236. [CrossRef]

2. Hein, L. Assessing the costs of land degradation: A case study for the Puentes catchment, southeast Spain. Land Degrad. Dev. 2007, 18, 631-642. [CrossRef]

3. Grainger, A. The role of science in implementing international environmental agreements: The case of desertification. Land Degrad. Dev. 2009, 20, 410-430. [CrossRef]

4. Gisladottir, G.; Stocking, M. Land degradation control and its global environmental benefits. Land Degrad. Dev. 2005, 16, 99-112. [CrossRef]

5. Zuindeau, B. Territorial Equity and Sustainable Development. Environ. Values 2007, 16, 253-268. [CrossRef]

6. Hammad, A.A.; Tumeizi, A. Land degradation: Socioeconomic and environmental causes and consequences in the eastern Mediterranean. Land Degrad. Dev. 2012, 23, 216-226. [CrossRef]

7. Abahussain, A.A.; Abdu, A.S.; Al-Zubari, W.K.; El-Deen, N.A.; Abdul-Raheem, M. Desertification in the Arab Region: Analysis of current status and trends. J. Arid. Environ. 2002, 51, 521-545. [CrossRef]

8. Portnov, B.A.; Safriel, U.N. Combating desertification in the Negev: Dryland agriculture vs. dryland urbanization. J. Arid. Environ. 2004, 56, 659-680. [CrossRef]

9. Amiraslani, F.; Dragovich, D. Combating desertification in Iran over the last 50 years: An overview of changing approaches. J. Environ. Manag. 2011, 92, 1-13. [CrossRef]

10. Wilson, G.A.; Juntti, M. Unravelling Desertification: Policies and Actor Networks in Southern Europe; Wageningen University Press: Wageningen, The Netherlands, 2005.

11. Becerril-Piña, R.; Mastachi-Loza, C.A.; González-Sosa, E.; Díaz-Delgado, C.; Bâ, K.M. Assessing desertification risk in the semi-arid highlands of central Mexico. J. Arid. Environ. 2015, 120, 4-13. [CrossRef] 
12. Beaumont, P.M.; Walker, R.T. Land degradation and property regimes. Ecol. Econ. 1996, 18, 55-66. [CrossRef]

13. Bojö, J. The costs of land degradation in Sub-Saharan Africa. Ecol. Econ. 1996, 16, 161-173. [CrossRef]

14. Atis, E. Economic impacts on cotton production due to land degradation in the Gediz Delta, Turkey. Land Use Policy 2006, 23, 181-186. [CrossRef]

15. Galeotti, M. Economic growth and the quality of the environment: Taking stock. Environ. Dev. Sustain. 2007, 9, 427-454. [CrossRef]

16. Patel, M.; Kok, K.; Rothman, D.S. Participatory scenario construction in land use analysis: An insight into the experiences created by stakeholder involvement in the Northern Mediterranean. Land Use Policy 2007, 24, 546-561. [CrossRef]

17. Imeson, A. Desertification, Land Degradation and Sustainability; Wiley: London, UK, 2012.

18. Blaikie, P.; Brookfield, H. Land Degradation and Society; Blaikie, P., Brookfield, H., Eds.; Routledge: London, UK, 2015; ISBN 9781315685366

19. Boyce, J.K. Inequality as a cause of environmental degradation. Ecol. Econ. 1994, 11, 169-178. [CrossRef]

20. Danfeng, S.; Dawson, R.; Baoguo, L. Agricultural causes of desertification risk in Minqin, China. J. Environ. Manag. 2006, 79, 348-356. [CrossRef]

21. Khresat, S.A.; Rawajfih, Z.; Mohammad, M. Land degradation in north-western Jordan: Causes and processes. J. Arid. Environ. 1998, 39, 623-629. [CrossRef]

22. Barbero-Sierra, C.; Marques, M.J.; Ruíz-Pérez, M. The case of urban sprawl in Spain as an active and irreversible driving force for desertification. J. Arid. Environ. 2013, 90, 95-102. [CrossRef]

23. Bestelmeyer, B.T.; Okin, G.S.; Duniway, M.C.; Archer, S.R.; Sayre, N.F.; Williamson, J.C.; Herrick, J.E. Desertification, land use, and the transformation of global drylands. Front. Ecol. Environ. 2015, 13, 28-36. [CrossRef]

24. Barbero-Sierra, C.; Marques, M.J.; Ruíz-Pérez, M.; Bienes, R.; Cruz-Maceín, J.L. Farmer knowledge, perception and management of soils in the Las Vegas agricultural district, Madrid, Spain. Soil Use Manag. 2016, 32, 446-454. [CrossRef]

25. Delfanti, L.; Colantoni, A.; Recanatesi, F.; Bencardino, M.; Sateriano, A.; Zambon, I.; Salvati, L. Solar plants, environmental degradation and local socioeconomic contexts: A case study in a Mediterranean country. Environ. Impact Assess. Rev. 2016, 61, 88-93. [CrossRef]

26. Juntti, M.; Wilson, G.A. Conceptualizing desertification in Southern Europe: Stakeholder interpretations and multiple policy agendas. Eur. Environ. 2005, 15, 228-249. [CrossRef]

27. Kok, K.; Patel, M.; Rothman, D.; Quaranta, G. Multi-scale narratives from an IA perspective: Part II. Participatory local scenario development. Futures 2006, 38, 285-311. [CrossRef]

28. Ibáñez, J.; Valderrama, J.M.; Puigdefábregas, J. Assessing desertification risk using system stability condition analysis. Ecol. Model. 2008, 213, 180-190. [CrossRef]

29. Li, C.-Z.; Crépin, A.-S.; Folke, C. The Economics of Resilience. Int. Rev. Environ. Resour. Econ. 2018, 11, 309-353. [CrossRef]

30. Le Houérou, H.N. Land degradation in Mediterranean Europe: Can agroforestry be a part of the solution? A prospective review. Agrofor. Syst. 1993, 21, 43-61. [CrossRef]

31. Capozzi, F.; Di Palma, A.; De Paola, F.; Giugni, M.; Iavazzo, P.; Topa, M.E.; Adamo, P.; Giordano, S. Assessing desertification in sub-Saharan peri-urban areas: Case study applications in Burkina Faso and Senegal. J. Geochem. Explor. 2018, 190, 281-291. [CrossRef]

32. Latorre, J.G.; García-Latorre, J.; Sanchez-Picón, A. Dealing with aridity: Socio-economic structures and environmental changes in an arid Mediterranean region. Land Use Policy 2001, 18, 53-64. [CrossRef]

33. Pérez-Sirvent, C.; Martínez-Sánchez, M.J.; Vidal, J.; Sánchez, A. The role of low-quality irrigation water in the desertification of semi-arid zones in Murcia, SE Spain. Geoderma 2003, 113, 109-125. [CrossRef]

34. Otto, R.; Krüsi, B.O.; Kienast, F. Degradation of an arid coastal landscape in relation to land use changes in Southern Tenerife (Canary Islands). J. Arid. Environ. 2007, 70, 527-539. [CrossRef]

35. Fernández, R.J. Do humans create deserts? Trends Ecol. Evol. 2002, 17, 6-7. [CrossRef]

36. Salvati, L.; Gemmiti, R.; Perini, L. Land degradation in Mediterranean urban areas: An unexplored link with planning? Area 2012, 44, 317-325. [CrossRef]

37. Gambella, F.; Bianchini, L.; Cecchini, M.; Egidi, G.; Ferrara, A.; Salvati, L.; Colantoni, A.; Morea, D. Moving toward the north? The spatial shift of olive groves in Italy. Agric. Econ. 2021, 67, 129-135. [CrossRef]

38. Herrmann, S.M.; Hutchinson, C.F. The changing contexts of the desertification debate. J. Arid. Environ. 2005, 63, 538-555. [CrossRef]

39. Zambon, I.; Benedetti, A.; Ferrara, C.; Salvati, L. Soil Matters? A Multivariate Analysis of Socioeconomic Constraints to Urban Expansion in Mediterranean Europe. Ecol. Econ. 2018, 146, 173-183. [CrossRef]

40. Kalantari, Z.; Ferreira, C.S.S.; Walsh, R.P.D.; Ferreira, A.J.D.; Destouni, G. Urbanization development under climate change: Hydrological responses in a peri-urban Mediterranean catchment. Land Degrad. Dev. 2017, 28, 2207-2221. [CrossRef]

41. Zucca, C.; Della Peruta, R.; Salvia, R.; Sommer, S.; Cherlet, M. Towards a World Desertification Atlas. Relating and selecting indicators and data sets to represent complex issues. Ecol. Indic. 2012, 15, 157-170. [CrossRef]

42. Carlucci, M.; Grigoriadis, E.; Rontos, K.; Salvati, L. Revisiting a Hegemonic Concept: Long-term 'Mediterranean Urbanization' in Between City Re-polarization and Metropolitan Decline. Appl. Spat. Anal. Policy 2017, 10, 347-362. [CrossRef]

43. Marathianou, M.; Kosmas, C.; Detsis, V. Land-use evolution and degradation in Lesvos (Greece): A historical approach. Land Degrad. Dev. 2000, 11, 63-73. [CrossRef] 
44. Briassoulis, H. The institutional complexity of environmental policy and planning problems: The example of Mediterranean desertification. J. Environ. Plan. Manag. 2006, 47, 115-135. [CrossRef]

45. Solecki, W.; Seto, K.C.; Marcotullio, P.J. It's Time for an Urbanization Science. Environ. Sci. Policy Sustain. Dev. 2013, 55, 12-17. [CrossRef]

46. Egidi, G.; Quaranta, G.; Salvia, R.; Salvati, L.; Včeláková, R.; Cudlín, P. Urban sprawl and desertification risk: Unraveling the latent nexus in a Mediterranean country. J. Environ. Plan. Manag. 2021, 65, 1-25. [CrossRef]

47. Rodrigo-Comino, J.; Salvia, R.; Egidi, G.; Salvati, L.; Giménez-Morera, A.; Quaranta, G. Desertification and Degradation Risks vs Poverty: A Key Topic in Mediterranean Europe. Cuad. De Investig. Geográfica 2021. [CrossRef]

48. Spyra, M.; Kleemann, J.; Calò, N.C.; Schürmann, A.; Fürst, C. Protection of peri-urban open spaces at the level of regional policy-making: Examples from six European regions. Land Use Policy 2021, 107, 105480. [CrossRef]

49. Verstraete, M.M.; Brink, A.B.; Scholes, R.J.; Beniston, M.; Stafford Smith, M. Climate change and desertification: Where do we stand, where should we go? Glob. Planet. Change 2008, 64, 105-110. [CrossRef]

50. Shaw, B.J.; van Vliet, J.; Verburg, P.H. The peri-urbanization of Europe: A systematic review of a multifaceted process. Landsc. Urban Plan. 2020, 196, 103733. [CrossRef]

51. Perrin, C.; Nougarèdes, B.; Sini, L.; Branduini, P.; Salvati, L. Governance changes in peri-urban farmland protection following decentralisation: A comparison between Montpellier (France) and Rome (Italy). Land Use Policy 2018, 70, 535-546. [CrossRef]

52. Salvati, L.; Zitti, M.; Sateriano, A. Changes in city vertical profile as an indicator of sprawl: Evidence from a Mediterranean urban region. Habitat Int. 2013, 38, 119-125. [CrossRef]

53. Salvati, L.; Zambon, I.; Chelli, F.M.; Serra, P. Do spatial patterns of urbanization and land consumption reflect different socioeconomic contexts in Europe? Sci. Total Environ. 2018, 625, 722-730. [CrossRef]

54. Cecchini, M.; Zambon, I.; Pontrandolfi, A.; Turco, R.; Colantoni, A.; Mavrakis, A.; Salvati, L. Urban sprawl and the 'olive' landscape: Sustainable land management for 'crisis' cities. GeoJournal 2019, 84, 237-255. [CrossRef]

55. Ciommi, M.; Chelli, F.M.; Carlucci, M.; Salvati, L. Urban Growth and Demographic Dynamics in Southern Europe: Toward a New Statistical Approach to Regional Science. Sustainability 2018, 10, 2765. [CrossRef]

56. Salvati, L.; Zitti, M. Territorial disparities, natural resource distribution, and land degradation: A case study in southern Europe. GeoJournal 2007, 70, 185-194. [CrossRef]

57. Simeonakis, E.; Calvo-Cases, A.; Arnau-Rosalen, E. Land use change and land degradation in southeastern Mediterranean Spain. Environ. Manag. 2007, 40, 80-94. [CrossRef]

58. Recanatesi, F.; Clemente, M.; Grigoriadis, E.; Ranalli, F.; Zitti, M.; Salvati, L. A fifty-year sustainability assessment of Italian agro-forest districts. Sustainability 2016, 8, 32. [CrossRef]

59. Salvati, L.; Zitti, M. Regional convergence of environmental variables: Empirical evidences from land degradation. Ecol. Econ. 2008, 68, 162-168. [CrossRef]

60. Wang, X.; Chen, F.; Dong, Z. The relative role of climatic and human factors in desertification in semiarid China. Glob. Environ. Change 2006, 16, 48-57. [CrossRef]

61. Kosmas, C.; Tsara, M.; Karavitis, C.A. Identification of indicators for desertification Effects of using treated municipal waste water for irrigation of olive trees in Greece. Ann. Arid. Zones 2003, 42, 393-416.

62. Iosifides, T.; Politidis, T. Socio-economic dynamics, local development and desertification in western Lesvos, Greece. Local Environ. 2006, 10, 487-499. [CrossRef]

63. Johnson, D.L.; Lewis, L.A. Land Degradation: Creation and Destruction, 2nd ed.; Rowman \& Littlefield: Lahnam, MD, USA, 2007.

64. Kairis, O.; Karavitis, C.; Kounalaki, A.; Salvati, L.; Kosmas, C. The effect of land management practices on soil erosion and land desertification in an olive grove. Soil Use Manag. 2013, 29, 597-606. [CrossRef]

65. Oxley, T.; Lemon, M. From social-enquiry to decision support tools: Towards an integrative method in the mediterranean rural environment. J. Arid. Environ. 2003, 54, 595-617. [CrossRef]

66. Mendelsohn, R.; Dinar, A. Climate, water, and agriculture. Land Econ. 2003, 79, 328-341. [CrossRef]

67. Hrubovcak, J.; LeBlanc, M.; Eakin, B.K. Agriculture, Natural Resources and Environmental Accounting. Environ. Resour. Econ. 2000, 17, 145-162. [CrossRef]

68. Hubacek, K.; Van Den Bergh, J.C.J.M. Changing concepts of "land" in economic theory: From single to multi-disciplinary approaches. Ecol. Econ. 2006, 56, 5-27. [CrossRef]

69. Lemon, M.; Seaton, R.; Park, J. Social enquiry and the measurement of natural phenomena: The degradation of irrigation water in the Argolid Plain, Greece. Int. J. Sustain. Dev. World Ecol. 2009, 1, 206-220. [CrossRef]

70. Capps, K.A.; Bentsen, C.N.; Ramírez, A. Poverty, urbanization, and environmental degradation: Urban streams in the developing world. Freshw. Sci. 2015, 35, 429-435. [CrossRef]

71. Broitman, D.; Czamanski, D.; Malkinson, D. Cities and Nature. Int. Rev. Environ. Resour. Econ. 2018, 12, 47-83. [CrossRef]

72. Oñate, J.J.; Peco, B. Policy impact on desertification: Stakeholders' perceptions in southeast Spain. Land Use Policy 2005, 22, 103-114. [CrossRef]

73. Pender, J.L. Population growth, agricultural intensification, induced innovation and natural resource sustainability: An application of neoclassical growth theory. Agric. Econ. 1998, 19, 99-112. [CrossRef]

74. Portnov, B.A.; Paz, S. Climate change and urbanization in Arid Regions. Ann. Arid. Zone 2008, 47, 457. [CrossRef] 
75. Tanrivermis, H. Agricultural land use change and sustainable use of land resources in the Mediterranean region of Turkey. J. Arid. Environ. 2003, 54, 553-564. [CrossRef]

76. Sakellariou, M.; Psiloglou, B.E.; Giannakopoulos, C.; Mylona, P.V. Integration of Abandoned Lands in Sustainable Agriculture: The Case of Terraced Landscape Re-Cultivation in Mediterranean Island Conditions. Land 2021, 10, 457. [CrossRef]

77. Yang, X.; Zhang, K.; Jia, B.; Ci, L. Desertification assessment in China: An overview. J. Arid. Environ. 2005, 63, 517-531. [CrossRef]

78. Prokopová, M.; Cudlín, O.; Včeláková, R.; Lengyel, S.; Salvati, L.; Cudlín, P. Latent Drivers of Landscape Transformation in Eastern Europe: Past, Present and Future. Sustainability 2018, 10, 2918. [CrossRef]

79. Loumou, A.; Giourga, C.; Dimitrakopoulos, P.; Koukoulas, S. Tourism contribution to agro-ecosystems conservation: The case of Lesbos Island, Greece. Environ. Manag. 2000, 26, 363-370. [CrossRef]

80. Luo, Y.; Sun, W.; Yang, K.; Zhao, L. China urbanization process induced vegetation degradation and improvement in recent 20 years. Cities 2021, 114, 103207. [CrossRef]

81. Makhzoumi, J.M. The changing role of rural landscapes: Olive and carob multi-use tree plantations in the semiarid Mediterranean. Landsc. Urban Plan. 1997, 37, 115-122. [CrossRef]

82. Scarascia, M.E.V.; Di Battista, F.; Salvati, L. Water resources in Italy: Availability and agricultural uses. Irrig. Drain. 2006, 55, 115-127. [CrossRef]

83. Emadodin, I.; Taravat, A.; Rajaei, M. Effects of urban sprawl on local climate: A case study, north central Iran. Urban Clim. 2016, 17, 230-247. [CrossRef]

84. Gohari, Z.; Nikou, S. Impacts of land use changes on Technogenic desertification in Mashhad city. Desert Ecosyst. Eng. J. 2017, 5, 81-90.

85. Rubio, J.L.; Bochet, E. Desertification indicators as diagnosis criteria for desertification risk assessment in Europe. J. Arid. Environ. 1998, 39, 113-120. [CrossRef]

86. Duvernoy, I.; Zambon, I.; Sateriano, A.; Salvati, L. Pictures from the other side of the fringe: Urban growth and peri-urban agriculture in a post-industrial city (Toulouse, France). J. Rural. Stud. 2018, 57, 25-35. [CrossRef]

87. Serra, P.; Saurí, D.; Salvati, L. Peri-urban agriculture in Barcelona: Outlining landscape dynamics vis à vis socio-environmental functions. Landsc. Res. 2018, 43, 613-631. [CrossRef]

88. Salvati, L.; Serra, P. Estimating rapidity of change in complex urban systems: A multidimensional, local-scale approach. Geogr. Anal. 2016, 48, 132-156. [CrossRef]

89. Ma, W.; Jiang, G.; Li, W.; Zhou, T. How do population decline, urban sprawl and industrial transformation impact land use change in rural residential areas? A comparative regional analysis at the peri-urban interface. J. Clean. Prod. 2018, 205, 76-85. [CrossRef]

90. Gkartzios, M. 'Leaving Athens': Narratives of Counterurbanisation in Times of Crisis. J. Rural. Stud. 2013, 32, 158-167. [CrossRef]

91. Kadhim, A.A.; Abbas, L.Z. Unplanned Urbanization and Agricultural Land Degradation in Baghdad City from 2003 to 2017. J. Coll. Educ. Women 2021, 32, 1-17. [CrossRef]

92. Li, W.; Wang, D.; Liu, S.; Zhu, Y. Measuring urbanization-occupation and internal conversion of peri-urban cultivated land to determine changes in the peri-urban agriculture of the black soil region. Ecol. Indic. 2019, 102, 328-337. [CrossRef]

93. Gkartzios, M.; Remoundou, K.; Garrod, G. Emerging Geographies of Mobility: The Role of Regional Towns in Greece's 'Counterurbanisation Story. J. Rural. Stud. 2017, 55, 22-32. [CrossRef]

94. Gkartzios, M.; Scott, K. A Cultural Panic in the Province? Counterurban Mobilities, Creativity, and Crisis in Greece. Popul. Space Place 2015, 21, 843-855. [CrossRef]

95. Petrişor, A.-I.; Hamma, W.; Nguyen, H.D.; Randazzo, G.; Muzirafuti, A.; Stan, M.-I.; Tran, V.T.; Aştefănoaiei, R.; Bui, Q.-T.; Vintilă, D.-F.; et al. Degradation of Coastlines under the Pressure of Urbanization and Tourism: Evidence on the Change of Land Systems from Europe, Asia and Africa. Land 2020, 9, 275. [CrossRef]

96. Salem, M.; Tsurusaki, N.; Divigalpitiya, P. Land use/land cover change detection and urban sprawl in the peri-urban area of greater Cairo since the Egyptian revolution of 2011. J. Land Use Sci. 2020, 15, 592-606. [CrossRef]

97. Spataru, A.; Faggian, R.; Docking, A. Principles of multifunctional agriculture for supporting agriculture in metropolitan peri-urban areas: The case of Greater Melbourne, Australia. J. Rural. Stud. 2020, 74, 34-44. [CrossRef]

98. Kairis, O.; Karavitis, C.; Salvati, L.; Kounalaki, A.; Kosmas, K. Exploring the impact of overgrazing on soil erosion and land degradation in a dry Mediterranean agro-forest landscape (Crete, Greece). Arid. Land Res. Manag. 2015, 29, 360-374. [CrossRef]

99. Moran Alonso, N.; Obeso Muniz, I.; Hernandez Aja, A.; Fernandez Garcia, F. Challenges for the revitalisation of peri-urban agriculture in Spain: Territorial analysis of the Madrid and Oviedo metropolitan areas. Morav. Geogr. Rep. 2017, 25, 192-207. [CrossRef]

100. Karamesouti, M.; Detsis, V.; Kounalaki, A.; Vasiliou, P.; Salvati, L.; Kosmas, C. Land-use and land degradation processes affecting soil resources: Evidence from a traditional Mediterranean cropland (Greece). Catena 2015, 132, 45-55. [CrossRef]

101. Ferrara, A.; Kosmas, C.; Salvati, L.; Padula, A.; Mancino, G.; Nolè, A. Updating the MEDALUS-ESA Framework for Worldwide Land Degradation and Desertification Assessment. Land Degrad. Dev. 2020, 31, 1593-1607. [CrossRef]

102. Bianchini, L.; Egidi, G.; Alhuseen, A.; Sateriano, A.; Cividino, S.; Clemente, M.; Imbrenda, V. Toward a dualistic growth? Population increase and land-use change in Rome, Italy. Land 2021, 10, 749. [CrossRef] 
103. Basso, F.; Bove, E.; Dumontet, S.; Ferrara, A.; Pisante, M.; Quaranta, G.; Taberner, M. Evaluating environmental sensitivity at the basin scale through the use of geographic information systems and remotely sensed data: An example covering the Agri basin (Southern Italy). Catena 2000, 40, 19-35. [CrossRef]

104. Liu, Y.; Wang, Y.; Peng, J.; Du, Y.; Liu, X.; Li, S.; Zhang, D. Correlations between urbanization and vegetation degradation across the world's metropolises using DMSP/OLS nighttime light data. Remote Sens. 2015, 7, 2067-2088. [CrossRef]

105. Slottje, D.; Nieswiadomy, M.; Redfearn, M. Economic inequality and the environment. Environ. Model. Softw. 2001, 16, 183-194. [CrossRef]

106. De Groot, R. Function-analysis and valuation as a tool to assess land use conflicts in planning for sustainable, multi-functional landscapes. Landsc. Urban Plan. 2006, 75, 175-186. [CrossRef]

107. Safriel, U.; Adeel, Z. Development paths of drylands: Thresholds and sustainability. Sustain. Sci. 2008, 3, 117-123. [CrossRef]

108. Ahani, S.; Dadashpoor, H. Land conflict management measures in peri-urban areas: A meta-synthesis review. J. Environ. Plan. Manag. 2021, 64, 1909-1939. [CrossRef]

109. Salvati, L.; Ciommi, M.T.; Serra, P.; Chelli, F.M. Exploring the spatial structure of housing prices under economic expansion and stagnation: The role of socio-demographic factors in metropolitan Rome, Italy. Land Use Policy 2019, 81, 143-152. [CrossRef]

110. Chelleri, L.; Schuetze, T.; Salvati, L. Integrating resilience with urban sustainability in neglected neighborhoods: Challenges and opportunities of transitioning to decentralized water management in Mexico City. Habitat Int. 2015, 48, 122-130. [CrossRef]

111. Gavalas, V.S.; Rontos, K.; Salvati, L. Who Becomes an Unwed Mother in Greece? Sociodemographic and Geographical Aspects of an Emerging Phenomenon. Popul. Space Place 2014, 20, 250-263. [CrossRef] 